Volume 11 Number 2, April-June 2017: pp. 109-121. Copyright (c) 2017 FIAT JUSTISIA. Faculty of Law, Lampung University, Bandarlampung, Lampung, Indonesia. ISSN: $1978-5186$ | e-ISSN: 2477-6238.

Open Access: http://jurnal.fh.unila.ac.id/index.php/fiat

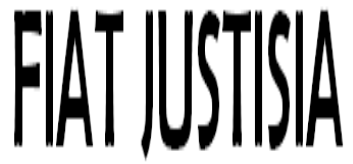

Fiat Justisia is licensed under a Creative Commons Attribution 4.0 International License, which permits unrestricted use, distribution, and reproduction in any medium, provided the original work is properly cited.

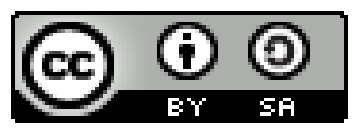

\title{
Strengthening the Integrity of Local Leadership and its Relevance to Run Democratic Governance
}

\author{
Maulana Mukhlis \\ Department of Government Science, Faculty of Social and Politic, \\ University of Lampung \\ maulanamukhlis1978@gmail.com \\ Idil Akbar \\ Department of Government Science, Faculty of Social and Politic, \\ University of Padjadjaran \\ idil.akbar@gmail.com
}

\begin{abstract}
Even though many aspects that show the way to run a democratic government, but the most important aspect is related to the leadership of integrity. The leadership of integrity put the perspective of power in the orientation of partisanship on the people. Also, democratic governance at the local level can be run effectively and constructively if the leadership held with integrity. In another word, the leadership of integrity is a requirement to run a democratic government. Therefore, the integrity of local leadership should be encouraged. Strengthening the integrity of local leadership includes two main things, namely giving a great opportunity for people participation and is committed to a clean and accountable government. Our conception of the strengthening the local leadership integrity and relevance of a democratic government explains important aspects of leadership in maintaining the continuity of a government. For success or failure of a reign depends on how to reach a democratic government that can be reached and gets the highest appreciation from the community. Therefore, the purpose of the writing of this article is to explain the significance between the leadership of integrity with democratic governance and elaborating how to strengthen the integrity of the leadership in the efforts to reach a democratic government.
\end{abstract}

Keywords: Leadership, Leadership Integrity, Democracy, Local Government, Democratic Governance. 


\section{A. Introduction}

The need for democratic governance is a reality nowadays. Why? In democratic governance, the meaning of the important presence of society becomes the subject of power. The presence of the society does not only appear while conducting the election but appear more in participating in the ongoing government process. In the implementation, democratic governance requires strong leadership and integrity. The leadership of integrity will be able to navigate the steps and policies taken by the government under his leadership in the direction that can give something useful for the society. Therefore, between leadership and governance are two subjects that are intertwined with each other, especially in a condition of how a government can run well and be democratic.

Leadership and government are two different theoretical concepts. The leadership is often interpreted as technic, path, styles, and strategy of a leader to influence others in the process of achieving the goals. While the government is the place or institution where the ruler (government) with people (ruled) are having interaction. Muslim and Hayati (2012) stated that the leadership of the government is the ability or skill of a leader to influence others in achieving the government goals. ${ }^{1}$ Even though the concept of theoretically is different, leadership and government have mutual contact with one another. One of them is to create a clean and accountable government and be able to invite the participation of the society to take part in the government. A leader who cannot lead the government will tend to ignore the problems faced by the community. In other words, the leader who conceives himself as a ruler tends to run the authoritarian government and mistreated.

Therefore the leader who is needed in the future is the one who has the integrity of leadership. The leadership of integrity is needed to get a democratic government. By that, the efforts to strengthening the leadership of integrity can be carried out with the best possibility. The era of direct elections of the District head is a business community to get a leader who is not only able to lead the government but also be able to provide solutions to all problems faced by the community. It is important to be noted the things that will be done by the leader as the result of running the mandate that has been given by the community. Based on that explanation it is important to explain the leader and leadership. That is why discourse about leadership is enough to be reviewed by the experts. However, the study of leadership still becomes an interesting topic for discussion. Most of the experts who put a question of leadership position are crucial enough, such as Mullins at \&

\footnotetext{
${ }^{1}$ Jayadi Nas, "Discourse Contemporary Government Leadership. Government", Jurnal Ilmu Pemerintahan, 8(1), (2015), pp. 1-7.
} 
Linehan (Mullins at \& Linehan, 2005) stated that leadership is the most important factor to compare with other factors in the success of an organization. ${ }^{2}$ While starch (2002) stated that quality and benefits of the organization became a responsibility of the leader. The leadership plays an important role in achievement for the organization. Also, Kangis \& Kelley (2000) stated that the role of leader gives motivation and harmonization for member's organization to achieve a goal.

Various definitions of integrated leadership have also revealed that basically, the integrative leadership includes on the attitude, nature, the behavior, and the force directs on the construction of lead as a leader in those who progressed including with the society. Huxman \& Vangen (2000), for example, define integrative leadership as a collaboration between the individual, the process, and the structure ${ }^{3}$. The leadership of the integration is also considered as the ability of the leadership qualities, behavior, styles, and variables situational, in a single theoretical model to explain the effectiveness of the leader ${ }^{4}$. It is defined as the attitude of integrative from the behavior of the leadership of the task, relationships and changes (Yulk, Gordon \& Taber, 2002), and defined as leadership that integrates elements of the transaction transformation and situation variables inherent in the various community context. ${ }^{5}$

Integrative leadership is also considered as the process of coordination from the conditions at the beginning of the process of the structure and stakeholders and problems as well as the results and accountability (Bryson, Crosby, \& Stone, 2006) and solidarity between leadership roles that oriented in the task, relationship, changes, the diversity and the integrity ${ }^{6}$. In the model of the cycle of the actions of the leadership, leadership is treated as a linear chain between causal factors related to the optimal leadership style options and depends on the conditions in the internal and external organization?

2 Mullins, J., \& Linehan, M, "The central role of leaders in public libraries", Library Management, 26(6), (2005), pp. 386-396.

${ }^{3}$ Huxham, C \& Vangen, S, "Leadership in the shaping and implementation of collaboration agendas: How things happen in a (not quite) joined-up world". Academy of Management Journal, 43(6), (2000), pp. 1159-1175.

${ }^{4}$ Yukl, G. A, Leadership in Organizations. Upper Saddle River, N.J: Prentice Hall, (2002).

5 Van Wart, M, Public-sector leadership theory: An assessment. Public Administration Review, 63(2), (2003), pp. 214-228.

${ }^{6}$ Fernandez, S., Cho, Y. J., \& Perry, J. L, "Exploring the link between integrated leadership and public sector performance", The Leadership Quarterly 21, (2010), pp. 308 - 323.

${ }^{7}$ Van Wart, M. Loc.Cit. 
The integrity is more than just the ethics. ${ }^{8}$ The integrity is a unity of the individual character. The integrity which causes the individual trust is a characteristic of persons who is consistently consider the compassion, attitudes, transparent, honest and ethical. The characteristics of the trust are connected with the integrity. We consider the individual who has integrity is the individual who acts according to the rights and the truth by leaders who deserve to be consistent. In the research, Dugar stated that individuals who have integrity in the conduct and actions are the individual that can be trusted and they are the defenders of the protection and be fair. Without integrity, no leader will be a success. ${ }^{9}$

The integrity is understood as the completeness, wholeness, unified and entirety; all refer to integrity. Integrity is meant cooperation of all aspects of life especially between words and deeds (Sendjaya, 2004). The Turknett Leadership Group explained that individuals who have integrity would not distort the facts for personal interests. They will stand up to defend the truth, still running his promises and can be expected to show the truth. For them, integrity is the foundation of leadership and is a prudent balance between honor and responsibility. The integrity is the basis for the individual, and without integrity, no leader can succeed. Turknett (2010) stated that individuals who have integrity would not deny the fact for personal gain. They will stand up and defend what is right. Integrity for leader involves the respect and the responsibility in conducting the job.

As conveyed by McKnight and Chervany (2001) which stated that the characteristics are the important thing to cause other people to believe it. Integrity is a part of the characteristics of the individual (Scheiders, 1965). Robbins (2006) stated that integrity of dimension is "the key" from the belief of the leader, which also means the four other dimensions namely competencies, consistency, loyalty, and openness, while the integrity is the most important dimension. ${ }^{10}$ So it is obvious that the leaders with the integrity need to do the best possible government. The trust from the society for the leader depends on how the leader can show the attitude, nature, and the behavior which is considered worthy in becoming the leader. Especially in the era of democracy nowadays, where the largest demand of the society towards the leader is being able to run a transparent, open, accountable government and able to avoid the act of corruption and be widely sided with the interests of the community.

\footnotetext{
${ }^{8}$ Dugar, J.W, The role of integrity in individual and effective corporate leadership. Journal of Academic and Bussiness Ethics the role of integrity, Holy family University, (2011), p. 1

${ }^{9}$ Linda Aryani, et.al., "Competency of Leaders Will Not Perfect Without Integrity", Jurnal Psikologi, 9(1), (2013), pp.31-39

${ }^{10}$ Robbins, S.P, Organization behaviour 10th edition, Jakarta: Indeks Gramedia, (2006).
} 


\section{B. Method}

The research is carried out using a qualitative approach to produce an in-depth explanation about the words, writing and behavior that can be observed from individual community groups and organizations in a specific context are examined from the apples, comprehensive and holistic approach. For the purpose of this research, researchers choose to use descriptive type research analytically so that the main steps of a research which is the description of the research object can be formulated by making it easier for the next step to do a deep and comprehensive analysis of the object that it is not intended to test the hypothesis, but only describe the variables, symptoms or the situation and perform analysis of the facts of the foundation for the guidelines in the future.

The data collected through the observation, in-depth interviews, and library research. The data analyzed used an analytical technique or data processing through the four stages, namely critical against data, data reduction, data classification, and interpretation. Meanwhile, validity and reliability data were done by the method of triangulation data.

\section{Discussion}

\section{The Leader Role in Creating a Democratic Governance}

The importance of a leader causes an organization such as government would never be able to walk better and optimum without a leader. Even though the leader exists, without the integrity, the administration will not have good progress. Because of that, there are five main roles of a leader in government, among others: First, the role of the decision-maker. It is about how a leader, especially in a bureaucracy, have authority to make decisions. Decision making is a managerial work that means deciding what must be done or not to be done, how to do it, who does it and when to be done. In this case, the specifications are the Subject, priority, strategies, formal structure, and allocation of the resources, performances of responsibility and setting of the activities.

The purpose is to make sure the organizing work unit efficient, coordination activities, and use of the resources to change. The most important aspect of most forms of decision making is deciding various activities in accordance with the interests of relatively unsophisticated (resource allocation), including planning still under construction procedures to avoid problems (potential problem analysis and development of procedures to perform quick and effective response to the issues of the scope of crises which cannot be avoided (contingency planning).

Second, the role of influence. A leader of bureaucracy must be able to give effect to his subordinates, so willing to cooperate in realizing the 
programs. The leader of the bureaucracy can develop various techniques which affect the subordinate and are easy for the leader of the public bureaucracy because the authority of the supervisor is very high. But if only rely on the mere authority, it will also not give the effect that means against the subordinate. The leader of the bureaucracy can change the authority and the advantages of the nature of which is own by a leader of the bureaucracy.

There are a few things that need to be noted is the role of the influence of the subordinate that is effective, that is:

a) Made a leader of the bureaucracy being honest, fair, and against all subordinate without special election;

b) Attempting to give an example of the work and act;

c) Be prudent and wise to subordinate that transgression;

d) Always involves the subordinate in various activities;

e) Grow a sense of confidence in the subordinate, that they have the ability and high work ethic;

f) Made subordinate felt valuable, treat them as a partner or teamwork.

Third, the role of motivation. A leader must be able to provide a boost to employees for more productive work. The influence of the relationship and the motivation is if the role of effective effect and the role of motivation will be easier to be done. On the contrary, if the leader is not able to invest the influence of his subordinates, it is difficult for him to understand a true character of his subordinates in different capabilities, knowledge, and behavior.

Four, inter-personal roles. A leader also plays strategic, especially inter-personal roles about a position as the leader of the bureaucracy. A leader is an appreciated figure. The leader must show their good attitudes such as the work ethos, discipline, and another positive attitude. Bureaucratic leaders must put themselves as a guardian, that has power, and the impetus for his subordinates.

Fifth, the role of the information. A leader should have informative, for the leader of the bureaucracy is the key holder, especially information about bureaucracy progress. A leader needs communicative ability to be an effective communicator. The role of being informative is explained to the subordinate regarding the plan's policies, and the expectations of the role and the instructions on how the work to be done by showing responsibility for the subordinate or other members, and purpose of the performance and the authority of the plan of action to achieve it.

The associated five roles above had infiltrated the democracy as a system of a government. Related to this, Diamond, Linz and Lipset stated that democracy as a system of government must meet the three main conditions, namely: 1) Serious competition and widespread among individuals and groups of the organization (especially political parties to 
compete for government positions that have effective power on regular time period and does not involve the use of force power; 2) Political participation involving people as many as possible in the leader election or the policy, at least through general election held on regular basis and fair, in such a way that none of the group that excluded; and 3) Civil liberties and political freedom of speech, the press freedom to form and join the organization, enough to guarantee. ${ }^{11}$

This is also delivered by Brinkerhoff (2000) related how democratic governance against the participation of citizens and political power (government). He said that the democratic governance combines characteristics of the political regime that gives citizens the rights to regulate themselves (democracy) with structure and mechanisms that are used to manage the public issue by the rules and procedures agreed (governance). Brinkerhoff defines democratic governance as "a set of procedures screened which assures meaningful competition among the broad participation in choosing the leaders and policies, and in the allocation of societal resources; and a high degree of civil, political and economic liberties. ${ }^{12}$ Other experts also give particular emphasis on democratic governance. Santioso (2000) stressed the accountability and transparency, the rule of law and anticorruption, as well as participation and decentralization. Although Brinkerhoff stressed the similar democratic element, he added that its emphasis on pluralism, policy reform of the state and respect for human rights. ${ }^{13}$ The role leader to achieve democratic governance is how the leaders can contribute to improving society, with attitudes and behavior that can be accepted. That is why, democratic governance stressed the existence of transparency, accountability, justice, and responsiveness. But more than that, the emphasis remains on leadership integrity.

Democratic governance itself has been popular by among others by March and Olsen (1995) ${ }^{14}$ who see the context that democracy in the cultural empiricism, confidence and the ethos that developed through the interpretation and practice. The focus is on the modern democratic governance, a choice in which democracy faced with limited himself and the uncertainty of its environment. Democratic governance at the beginning is known as a mechanism for management in a small city and is developed

\footnotetext{
11 Idil Akbar, "Concurrent local election and stories of political dynamics and the local government of Indonesia", CosmoGov, 2 (1), (2017), pp. 95-110.

12 Brinkerhoff, Derick W, "Democratic governance and sectoral policy reform: tracing linkages and exploring synergies", World Development, 28 (4), (2000), pp.601-615.

13 Santioso, Carlos, towards democratic governance the contribution of the multilateral development banks in Latin America. In Peter Burnell (ed). Democracy assistance: international cooperation for democratization, London: Frank Cass Publisher, (2000).

${ }_{14}$ March, James G., and Olsen, Johan P, Democratic Governance. New York: Free Press, (1995), pp. 8-9.
} 
over the centuries as a model of management countries that are relatively small and with a small population.

Based on the presentations, we understand democratic governance more as a modern democratic life practice that was held in professional manners. It is understanding gives us the comprehension that the concept of "democratic governance" is still in the corridor of the "democratic" system that requires each policy-making process by the state (state) must involve the people (civil society); the process of such involvement does not have patterned mobilization, but the participation and based on the principles of good governance, that is transparency, accountability, justice, and responsiveness.

\section{The leadership integrity: effort to build trust in public services}

Integrity is closely related to public trust. It means that the public trust in the leader is very dependent on how far the leader can show himself as the figure of integrity with all important aspects that become the integrity indicator. The integrity at this time can be categorized as something impossible owned caused by the multitude of interests, and the will of the leader is essentially a blatant attempt to search for personal gain. Therefore, it is fair if the integrity is considered as a quality or nature of the behavior which rarely exists. Even by many people, is referred to as the quality that almost extinct. John C. The Maxwell, says: "Unfortunately, integrity is a commodity that began to disappear this time. The personal standard is falling apart in the world who guarded the pursuit of personal pleasure and shortcuts to success jealously. ${ }^{15}$ Then, the integrity is considered important as a crucial foundation for public trust towards the leader. It is delivered by Warren Bennis in his book entitle Leaders: The Strategies for Taking Charge that integrity is the foundation to build trust (trust). Trust is closely related to the predictability. A leader who has the integrity of building trust could be able to show to other people that when facing the with moral challenges, transparent in every decision and could be predictably spiraled. ${ }^{16}$

A trusted leader is the leader who has integrity, competency, loyalty to subordinates and for his work and trusted by his subordinates. Wirawas (2008) stated that a leader who has a high degree of integrity usually has an honest attitude keeps the commitment and behaves consistently. Integrity is necessary for leadership. People with the assessment of people who can trust tend to reach the achievements of the plan and work hard, rarely have difficulty. Those who have the value of lace tend not be organized, cannot be

\footnotetext{
${ }^{15}$ Maxwell, John. C, Developing leadership in yourself, Jakarta: Binarupa Aksara, (1995), p. 37.

${ }^{16}$ Rukku, Maria and Ronda, Daniel. Leaders who have the integrity according to 2 Timothy chapter 2. Jaffray, 9 (1), (2011), pp. 25-59.
} 
trusted and often surrender if facing challenges. ${ }^{17}$ Trust is important because it helps regulate the complexity, help to develop action capacity, increase the ability for collaboration and improve learning organization. Trust is a willingness to hinges on others where we have trusted him, and without trust as a core of every human relations, a supervisor will not be able to complete the task that charged him well. To get the trust of his subordinates, a supervisor should be competent to work, reliable by his subordinates, open and concerned about his subordinates. ${ }^{18}$

That is why the leader integrity has certain characteristics that are empirically visible in the behavior of his leadership. The intended behavior among others: first, sincerity. Sincerity is the behavior without a sham and a false impression. The leaders of integrity are sincere -- their actions are by his word. The leaders of integrity have characters that are not hypocrites. His does everything coherently with his words. Second, consistency. One real work that shows the integrity will leave the impression, but the behavior of a leader must be consistent if he wants to have successfully formed an organization. Integrity is directive because one piece of violation only of the integrity will be able to leave the permanent disablement. The leaders must be consistent in running the standard discipline. A leader who is discriminated against, using the level of the kingship or friend relationship to decide its response to a breach of discipline, have a serious integrity issue.

Third, the strength of the heart. A leader must have more than just the image of himself (image) of having integrity, i.e., must have the strength of heart. The leaders from the outside looks to have the strength of heart, but found in it the lack of integrity will not strong enough to survive in difficult times. The leader of weak integrity cannot build organizations that can survive in a situation that is full of challenges.

Fourth, was able to survive until the end. A leader can show integrity by implementing the best possible task, regardless of how important the task or who will get the praise. The leaders of integrity will not see what a burden is not a load.

Therefore, no one if James Kousez and Barry Posner, two prominent researchers, in their book entitled Credibility: How leaders gain and lose it, why people demand it states - in his research report for almost 20 years of

\footnotetext{
${ }^{17}$ Zahra, Elvira, "The influence of the integrity, competency and customer loyalty leadership of the belief of the subordinate In SBU Shipping PT Pusri Palembang". Jurnal Ilmiah Orasi Bisnis, (2011).

${ }^{18}$ Yulianti and Wuryanti, "The influence of transformational leadership, the integrity of the behavior and the belief of leadership in improving the performance of human resources (Study BLHKP, BKPPD and BPMP Konawe district, South East Sulawesi Province)". Proceeding of $2^{\text {nd }}$ Conference In Business, Accounting And Management (CBAM). 2 (1), (2012), pp. 282-300.
} 
survey results to thousands of professionals from four continents and hundreds of the case study - that the number one factor that most critical for a leader is the integrity. ${ }^{19}$ It is clear that leadership is one of the main key factors in the life of any organization including government. Thoha (2004) stated that an organization would succeed or even failed to most which are determined by leadership. The leadership problems are important for making the leader has always been the focus of the evaluation about the cause of the success or failure of the organization. The task leader (Goleman, 2002) is created on what he termed as resonance, a positive atmosphere that can make all the human resources in the organization continue to bind themselves (the trainer needs to) and give the best for the organization. So also Schein (1992) stated that the leaders had a great impact on the success the organization can face the challenges that appear.

The demands for the quality and performance of the leadership in the conduct of the administration surfaced and continued to increasingly become the patron a leader and potential leader in bringing change in the organization and motivate its members to achieve the goal of the organization. The leadership is the basis in the management of human resources which is expected to not only be on the operational aspect in the establishment of the quality of life of the work but also on the underlying strategic aspects of the formation of the work-life conditions. From the perspective of public services, leaders must be able to bring the public organization provides excellent service. First and foremost on the heels of the public organization is to offer services to the community. Tangkilisan (2005) said that public organization is said to effective when in reality its implementation of bureaucracy can serve in accordance with the needs of the community (client), means no obstacles (roomy) that occurred in the services, fast and precise in magnitude- 6.6 services, and able to troubleshoot the prominent phenomenon due to social change that comes from the external factors. The effectiveness of public organizations is the product of a system that one system (elements) is the human resources reform. As part of a system, increasing the professionalism of the human resources reform is not automatically increase the performance of the public organizations. So when the human resources professional has apparatus but is not supported by the sub-subsystem such as institutional, governance, adequate facilities, and infrastructure performance would include the corresponding public organizations will not be able to reach the level of optimal performance.

About the public confidence, public confidence grows from the quality of service. In line with the OECD statement (2000), the public service is a public trust. "Public service is a public trust. Citizens expect

${ }^{19}$ Rukku, Maria and Ronda, Daniel. Loc. Cit. 
public servants to serve the public interest with fairness and to manage public resources properly on a daily basis. Fair and reliable public services inspire public trust and create a favorable environment for businesses, thus contributing to well-functioning markets and economic growth," Thus the quality of public services is one of the strategic issues for the state apparatus that should be implemented into the framework of building public confidence. ${ }^{20}$ As an embodiment of these things, leaders are significant factors. The role of leader in building public trust includes the internal scope related to move and make sure the entire apparatus resources highperformance and scope of external organizations in efforts to consider the public expectations and communication, especially public service measures, the ongoing efforts, is being and will be done as well as services performance that has been produced.

\section{Conclusion}

The value of democracy has various important indicators such as the participation of public accountability, transparency and so on. However, relation with leadership, the scope of the importance of the construction of the values of democracy is the integrity. A leader must own the integrity of a crucial foundation. Integrity is the foundation for anyone. The absence of integrity will not make successful leaders achieve democratic governance.

The role of the leader to achieve democratic governance covering five main things such as decision-makers, the role of affection, gives the motivation to give an example, provides information and communicative. Remixing the whole role of this will not be easy if a leader does not have the integrity that can become the guidance in building trust by the public and his subordinates.

The public trust wakes up from the public services that are good. In the bringing of public services that the sink, a leader must be able to navigate all the owned resources to provide optimal services to the public. The leader has a great influence to determine the successful ongoing governance process.

\footnotetext{
${ }^{20}$ Sanapiah, Aziz. The dimensions of the leadership of the apparatus in the perspective of Public services: building the trust. Retrieved August 30, 2017, from https://www.stialan.ac.id/artikel/artikel\%20aziz.pdf
} 


\section{Bibliography}

\section{A. Book}

Covey. S. (1997). 8th habits. Jakarta: Binarupa Aksara.

Dugar, J.W. (2011). The role of integrity in individual and effective corporate leadership. Journal of Academic and Bussiness Ethics the role of integrity. Holy family University.

Fernandez, S., Cho, Y. J., \& Perry, J. L. (2010). Exploring the link between integrated leadership and public sector performance. The Leadership Quarterly 21

March, James G, and Olsen, Johan P. (1995). Democratic Governance. New York: Free Press

Maxwell, John. C. (1995). Developing leadership in yourself. Jakarta: Binarupa Aksara

Robbins, S.P. (2006). Organization behaviour 10th edition. Jakarta: Indeks Gramedia.

Santioso, Carlos. (2000). Towards democratic governanceL the contribution of the multulateral development banks in Latin America. In Peter Burnell (ed). Democracy assistance: international cooperation for democratization. London: Frank Cass Publisher.

Yukl, G. A. (2002). Leadership in Organizations. Upper Saddle River, N.J: Prentice Hall.

\section{B. Journal and Proceeding}

Aryani, Linda, et al., "Competency of Leaders Will Not Perfect Without Integrity." Jurnal Psikologi, 9(1), (2013).

D Muijs, "Leadership and organizational performance: from research to prescription?" International Journal of Educational Managemen, 25(1), (2011).

Derick W Brinkerhoff, "Democratic governance and sectoral policy reform: tracing linkages and exploring synergies," World Development, 28(4), (2000).

Elvira Zahra, "The influence of the integrity, competency and customer loyalty leadership of the belief of the subordinate In SBU Shipping PT Pusri Palembang." Jurnal Ilmiah Orasi Bisnis, (2011).

Huxham, C., \& Vangen, S. (2000). "Leadership in the shaping and implementation of collaboration agendas: How things happen in a (not quite) joined-up world." Academy of Management Journal, 43(6)

Idil Akbar, "Concurrent local election and stories of political dynamics and the local government of Indonesia." CosmoGov, 2(1), (2017). 
Mullins, J, \& Linehan, M, "The central role of leaders in public libraries." Library Management, 26(6), (2005).

Nas, Jayadi, "Discourse Contemporary Government Leadership. Government", Jurnal Ilmu Pemerintahan. 8(1), (2015).

Rukku, Maria, and Ronda, Daniel, "Leaders who have the integrity according to 2 Timothy chapter 2" Jaffray, 9(1), (2011).

Van Wart, M. (2003). Public-sector leadership theory: An assessment. Public Administration Review. 63(2)

Yulianti and Wuryanti, "The influence of transformational leadership, the integrity of the behavior and the belief of leadership in improving the performance of human resources (Study BLHKP, BKPPD and BPMP Konawe district, South East Sulawesi Province)," Proceeding of $2^{\text {nd }}$ Conference In Business, Accounting And Management (CBAM), 2(1), (2012).

\section{World Wide Web}

Sanapiah, Aziz. The dimensions of the leadership of the apparatus in the perspective of public services: building the trust. Retrieved August 30, 2017, from https://www.stialan.ac.id/artikel/artikel\%20aziz.pdf 